\title{
Is the perception of anxiety in dental care by children and their parents concordant?
}

\section{A percepção da ansiedade no atendimento odontológico pelas crianças e por seus pais são concordantes?}

\author{
Aline TRAVESSINI ${ }^{1}$ iD https://orcid.org/0000-0002-1559-2227

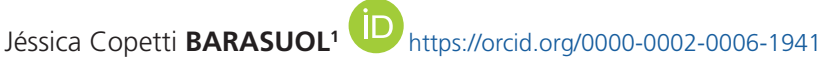 \\ Josiane Pezzini SOARES ${ }^{1}$ iD https://orcid.org/0000-0003-4412-7647 \\ Mariane CARDOSO1 ID https://orcid.org/0000-0001-9936-7942 \\ Michele BOLAN ${ }^{1}$ iD https://orcid.org/0000-0002-2835-9061
}

\begin{abstract}
Objectives: This research evaluated the caregivers' perception on dental anxiety of their children and verified its association with independent variables: caregivers' dental anxiety and the reason for their last dental appointment, socioeconomic factors, caregivers and children's last dental visit, children's oral health status, dental anxiety and kind of dental appointment. Methods: Fifty-eight children aged 6 to 9 years old and their caregivers participated in the study. For this cross-sectional study the participants were selected from a clinical study where half of the children received fluortherapy and the other half tooth extraction. The caregivers answered questions about socioeconomic status and to evaluate their dental anxiety and the perception on children's dental anxiety they answered the Dental Anxiety Scale and Dental Anxiety Question, respectively. To evaluate children's dental anxiety the Modified Venham Picture Test was applied and their oral health status was verified with the DMFT index. Data were analyzed with Chi-square, Fisher's Exact and Mann-Whitney's test. Results: The frequency of the caregivers' perception on dental anxiety of their children were $50.9 \%$. However, $41.4 \%$ of children reported dental anxiety. There was a significant difference between Dental Anxiety Question and Modified Venham Picture Test $(p=0.002)$. There was no relationship between caregivers' perception on dental anxiety of their children and other independent variables. Conclusion: There was a significant difference between children's dental anxiety and the perception of it by those caregivers.
\end{abstract}

Indexing terms: Child. Dental anxiety. Oral health.

\section{RESUMO}

Objetivos: Este trabalho avaliou a percepção dos responsáveis sobre a ansiedade odontológica das crianças e sua associação com as variáveis independentes: ansiedade odontológica dos responsáveis e o motivo para sua última consulta odontológica, fatores socioeconômicos, última visita ao dentista dos responsáveis e da criança, condição bucal da criança e tipo de procedimento odontológico realizado na consulta. Métodos: Neste estudo transversal a amostra contou com 58 crianças entre 6 e 9 anos e seus responsáveis.

\footnotetext{
1 Universidade Federal de Santa Catarina, Departamento de Odontologia, Programa de pós-graduação em Odontologia. Campus Universitários, Trindade, 88040-900, Florianópolis, SC, Brasil. Correspondence to: JC BARASUOL. E-mail: <jessica.barasuol@hotmail.com>. 
Os participantes foram selecionados a partir de um estudo clínico em que metade das crianças receberam fluorterapia e as outras exodontia. Os responsáveis responderam ao questionário socioeconômico e para avaliar a ansiedade odontológica e a percepção sobre a ansiedade odontológica das crianças eles responderam a Dental Anxiety Scale e a Dental Anxiety Question, respectivamente. Para avaliar a ansiedade odontológica das crianças foi aplicado o Venham Picture Test Modificado e a sua condição bucal foi verificada pelo índice CPO-D/ceo-d. A análise dos dados foi realizada pelo teste Qui-quadrado, Exato de Fisher e Mann-Whitney. Resultados: A frequência de responsáveis que perceberam a ansiedade odontológica das crianças foi de 50,9\%. Entretanto, 41,4\% das crianças relataram a ansiedade odontológica. Houve uma diferença significativa entre o Dental Anxiety Question e o Venham Picture Test Modificado $(p=0,002)$. Não houve relação entre a percepção dos responsáveis sobre a ansiedade odontológica das crianças com as demais variáveis independentes. Conclusão: Existiu uma diferença significativa entre a ansiedade odontológica das crianças e a percepção desta pelos responsáveis.

Termos de indexação: Criança. Ansiedade ao tratamento odontológico. Saúde bucal.

\section{INTRODUCTION}

Anxiety about dental treatment is a feeling that comes from situations related to care that can cause apprehension, discomfort, and, consequently, provide a negative experience to the patient [1]. The prevalence of dental anxiety in children can vary according to the instrument used to measure it, the environment where it is performing, the child's age, among other factors. In a longitudinal study involving 416 Brazilian schoolchildren aged 5 to 7 years, it was observed through the Dental Anxiety Question (DAQ), applied to children, in which the prevalence of dental anxiety was $16.2 \%$ and its incidence was $15 \%$ over the years of follow-up [2]. Another randomized clinical study from the University of São Paulo showed dental anxiety in $27 \%$ of a total of 100 children between 3 and 5 years of age assessed by the Facial Image Scale (FIS) [3].

Many factors are related to this feeling, such as age, gender, previous experience at the dentist, history of dental pain, and caries disease $[2,3]$. There is evidence that the child's dental anxiety can be influenced by the dental anxiety and education of the parents and be an important barrier to the search for dental care, reflecting a deficient oral condition [4]. Besides, children are dependent on their guardians to maintain their oral health, as well as to gain access to health services [5].

To be successful in child dental treatment, the dentist must know how to understand the child's emotions, but for this, a careful interpretation of his behavior is necessary [6]. Anxiety about dental treatment is an unpleasant feeling and the child may have difficulty expressing it. Often, the parents' perception of their children's dental anxiety can assist the professional in conducting the treatment, or else have a positive or negative influence on the search for consultations [5].
Studies must be carried out to observe if the perception of those responsible for children's dental anxiety is truly consistent with the dental anxiety described by them, as well as studying the factors that are associated with this perception. Therefore, the main objective of this study was to verify whether the guardians' perception of children's dental anxiety is associated with children's dental anxiety.

\section{METHODS}

\section{Ethics Committee}

This work was approved by the Ethics Committee on Research with Human Beings under the number $2,308,475 / 2017$. The guardians and the children who agreed to participate signed the Free and Informed Consent Form (ICF).

\section{Sample selection}

This cross-sectional survey included a convenience sample of 58 children referred by the Regulation System of the municipality (SISREG), 29 received fluorotherapy, and 29 extractions, of both sexes, belonging to the age group of 6 to 9 years, accompanied by their guardians. For the sample calculation, children with dental anxiety measured by the DAQ and $31.2 \%$ of their parents with moderate to high anxiety and $68 \%$ of them with low dental anxiety [7] were considered, a significance level of $5 \%$ and test power of $80 \%$, totaling 27 parent/child pairs for each group. The place of data collection was in a dental clinic of graduation in Dentistry from March to October 2017.

For the children to be included in this study, the criteria were: children aged 6 to 9 years, who had not 
previously undergone fluorotherapy or extraction and literate guardians.

The exclusion criteria used were children with fixed orthodontic devices, neurological problems, presence of systemic complications in the general health situation, use of continuous medication, refusal to participate in the research and the absence of signing the informed consent form.

\section{Data collection}

\section{Questionnaire to those responsible}

The guardians' perception of children's dental anxiety was verified by the Dental Anxiety Questionnaire (DAQ), which consists of a question translated into Brazilian Portuguese and used by other authors such as Colares et al. [8] and Soares et al. [9] The question is: "Is your child afraid of going to the dentist?", And the answers may be: "No", "Yes, a little", "Yes, he/she is afraid" or "Yes, he/she is very afraid ". This variable was dichotomized into with anxiety (responses: "Yes, a little", "Yes, he/she is afraid" or "Yes, he/she is very afraid") and without anxiety (response: "No").

Parents' dental anxiety was assessed using the Dental Anxiety Scale (DAS) developed by Corah [10] and was subsequently translated and validated into Brazilian Portuguese [11]. This instrument contains four questions, with five answers related to the reactions felt by the patient when he goes to the dentist. Each answer has a score ranging from 1 to 5 (less anxious to extremely anxious). The total score of the questionnaire ranges from 4 to 20 . Thus, DAS with a score of 11 represents low dental anxiety, 12 to 14 moderate and DAS $\geq 15$ indicates high anxiety [12].

A questionnaire with questions related to socioeconomic factors was also delivered. Among the issues were the education level of the parents, monthly family income, last visit to the dentist, and reason for the last dental appointment. Also, there were questions regarding the child such as age, dental pain in the last 6 months, and last visit to the dentist.

Dental anxiety assessment and children's oral condition

Before starting dental procedures for tooth extraction or fluorotherapy, the guardians and the children received explanations regarding what would be done. Then the Modified Venham Picture Test (VPTm) was presented to the child, which was used to check the child's dental anxiety. This test was validated for Brazilian children and has 8 pairs of children's figures expressing positive and negative behavior reactions [13]. At this point, they were asked: "Which figure represents what you are feeling at the moment?", So that she could choose the figure that best represented her feeling. When the child chose the figure with a negative reaction, the score was 1 (one) indicating the presence of dental anxiety and the figure with a positive reaction had a score of 0 (zero). The final result ranged from 0-8 and the variable was dichotomized into: with anxiety $(\geq 1)$ and without anxiety (0 - zero).

The children clinical examination consisted of assessing the presence ( $\geq 1$ decayed tooth) or absence ( 0 - healthy teeth) of decayed teeth (D) of the DMFT and $\mathrm{dmft}$ index [14]. The diagnosis of dental caries was based on clinical visual examination, using artificial light, mouth mirror \# 5 and sterile WHO probe and with the patient sitting in the dental chair, following the standards of the World Health Organization described [14]. The data obtained were recorded in a form developed for this research.

After the application of the VPTm and the clinical examination, the children were submitted to fluorotherapy or extraction by a single operator.

\section{Statistical analysis}

The data were tabulated in the SPSS Statistics 20.0 software (SPSS, Chicago, IL, USA). The descriptive analysis was performed and afterward, the Chi-square, Fisher's Exact, and Mann-Whitney tests were applied to verify if there was an association between the dependent variable (DAQ) and the independent variables, considering a significance level of $5 \%$.

\section{RESULTS}

A total of 60 parents/guardians of their children were invited to participate in the research. However, 2 were excluded for not having completed the questionnaires properly. Therefore, a total of 58 pairs of parents/guardians and children were included in the analysis. 
Table 1 shows the distribution of all variables collected. Boys predominated in the survey, and the average age of the participants was 7.5 years (SD 1.04). Among the children, the majority reported pain of dental origin in the six months preceding the survey. However, more than half of the children visited the dentist during this period. The frequency between parents who perceived their children's dental anxiety or not was similar.
Table 2 shows the relationship between the dependent variable, parents' perception of children's dental anxiety (DAQ), and the independent variables. According to the data, there was a significant difference between the perception of parents/guardians regarding children's dental anxiety and children's dental anxiety (VPTm) ( $p=0.002)$. Thus, $41.4 \%$ of the children had dental anxiety, but $50.9 \%$ of the parents/guardians perceived this anxiety through the DAQ.

Table 1. Distribution of frequency of socioeconomic and dental characteristics of children and parents/guardians, Florianopolis (SC), 2017. ( $n=58)$.

\begin{tabular}{|c|c|c|c|}
\hline \multirow[t]{2}{*}{ Children's data } & & \multicolumn{2}{|c|}{ Total } \\
\hline & & $\mathbf{n}$ & $\%$ \\
\hline Sex & Male & 34 & 58.6 \\
\hline \multirow[t]{3}{*}{ Age (years) } & 6 & 14 & 24.1 \\
\hline & 7 & 16 & 27.6 \\
\hline & 8 & 18 & 31.1 \\
\hline \multirow[t]{2}{*}{ Last visit to the dentist* } & 6 months & 37 & 64.9 \\
\hline & $>6$ months & 20 & 35.1 \\
\hline \multirow[t]{2}{*}{ Dental pain* } & No & 16 & 28.1 \\
\hline & Yes & 41 & 71.9 \\
\hline$D-D M F T$ & 0 & 52 & 89.7 \\
\hline \multirow[t]{2}{*}{ Dental anxiety (VPTm) } & Without anxiety & 34 & 58.6 \\
\hline & With anxiety & 24 & 41.4 \\
\hline \multirow[t]{2}{*}{ Parents' perception of children's dental anxiety $\left(D A Q^{*}\right.$} & Without anxiety & 28 & 49.1 \\
\hline & With anxiety & 29 & 50.9 \\
\hline \multirow[t]{2}{*}{ Procedure } & Fluorotherapy & 29 & 50 \\
\hline & Tooth extraction & 29 & 50 \\
\hline \multicolumn{4}{|l|}{ Parents/guardians data } \\
\hline \multirow[t]{2}{*}{ Education level } & $>8$ years & 21 & 36.2 \\
\hline & $\leq 8$ years & 37 & 63.8 \\
\hline Monthly family income & $>3 \mathrm{MW}$ & 10 & 17.2 \\
\hline \multirow[t]{3}{*}{ Dental anxiety (DAS) } & Low & 55 & 94.8 \\
\hline & Moderate & 3 & 5.2 \\
\hline & High & 0 & - \\
\hline
\end{tabular}

Note: D-DMFT/d-dmft (decayed component of the index of decayed, lost and filled permanent and decayed teeth); VPTm (Modified Venham Picture Test); DAQ (Dental Anxiety Question); MW (Minimum wage=R\$937,00); DAS (Dental Anxiety Scale); ${ }^{*}=57$. 
Table 2. Association of parents/guardians' perception of children's dental anxiety and independent variables. Florianopolis (SC), 2017.

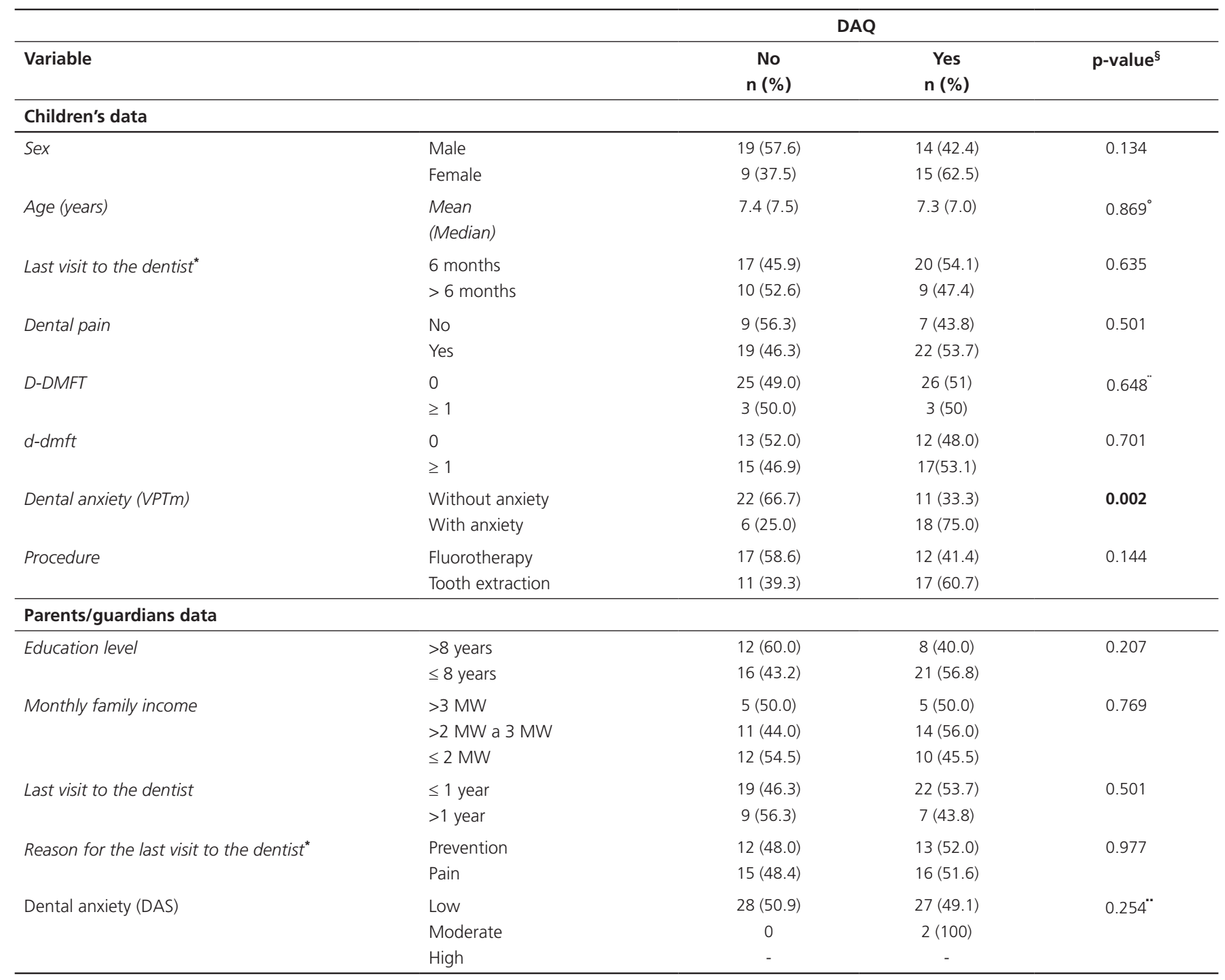

Note: ${ }^{*} \mathrm{n}=56 ;^{\S}$ Chi-square test; ${ }^{*}$ Fisher's Exact test; ${ }^{\circ}$ Mann-Whitney test.

\section{DISCUSSION}

The present study obtained as the main result a significant difference between the perception of parents/ guardians regarding children's dental anxiety and the dental anxiety reported by them.

In this research, children had less dental anxiety than their parents perceived, this is an important outcome to be considered in dental practice because sometimes dentists ask the parents if the child is anxious and how his behavior is. Information about the child's dental anxiety can be useful for professionals to prepare the treatment plan, since behavioral problems may arise during the administration of local anesthesia, for example [15].
According to Oliveira et al. [6], knowledge about children's dental anxiety helps in predicting the child's behavior, as well as in the success of care.

Some authors have observed that parents can predict their children's dental anxiety $[16,17]$. Cianetti et al. [16] in their systematic review, observed the frequency of children's dental anxiety in $12.3 \%$, similar to that reported by parents (12.9\%).

Other studies have also used the Dental Anxiety Question (DAQ) as an instrument to obtain information about children's dental anxiety through parents' reports. Colares et al. [8] observed a prevalence of dental anxiety of $39.4 \%$ in children aged 5 to 12 years, and the data were 
collected in a municipal park. In the longitudinal study by Soares et al. [9], schoolchildren, between 5 and 7 years old, had a prevalence of $17.4 \%$. In another survey conducted in preschools, dental anxiety among children aged 5 to 9 years ranged from $16.2 \%$ to $18.9 \%$ in two years [2]. The frequency of this research was higher in relation to the others, and this may be due to the environment where the questionnaire was applied, since the parents took their children to the dental care for some procedure, and this may have maximized their perception. In addition, the samples are different as well as the methodology used.

There was no association between children's perception of dental anxiety and the guardians' own dental anxiety. This result demonstrates that the guardians' anxiety was not a confounding factor that could have influenced their perception of children's anxiety, and this may increase the credibility of the data. Vasiliki et al. [15] also concluded that there was no significant correlation between children's dental anxiety and that of their parents. Differently, from the studies by Colares et al. [8] and Olak et al. [18] that observed this association.

In addition, there was no relationship between the guardians' perception of children's dental anxiety and socioeconomic factors. However, according to Soares et al. [9], lower family income increases the chances of high dental anxiety among children according to the parents' report. According to Colares et al. [8], the highest levels of maternal education are inversely proportional to children's dental anxiety when the DAQ was answered by the children.

The child's oral condition was not associated with the guardians' perception of dental anxiety, in the same way as the type of procedure the child underwent. Soares et al. [9] found no association between physical wellbeing, understood as "limitation due to physical health problems or illness in the last month", and children's dental anxiety perceived by their parents. However, other studies that evaluated dental anxiety reported by children demonstrated that the presence of caries and dental pain was related to higher levels of dental anxiety [8,18-21]. The divergences in the results of this study, when compared to the others, maybe due to the different methodologies, age groups, places of execution of the research, inclusion and exclusion criteria of the participants, instruments used to measure the outcomes.

Some characteristics of this study deserve to be highlighted, such as the use of the DAQ, which is a questionnaire used to assess dental anxiety in Brazilian children $[8,9]$, is quick to be applied, easy to understand, does not require the identification of the participant and can be answered without any embarrassment on the part of the interviewee, in the same way as the socioeconomic questionnaire. In addition, the age range of the children in the survey allows understanding to respond to the Modified Venham Picture Test (VPTm).

Some methodological aspects have limitations, such as the convenience sample, which does not allow extrapolation of data to other children who do not have the same characteristics as the participants in this study. And because it is a cross-sectional study, it is not possible to investigate the causes of dental anxiety in children. According to the results of this study, caregivers can overestimate children's dental anxiety, so it is necessary to develop future research aiming at a greater understanding of dental anxiety and its causal factors.

\section{CONCLUSION}

There was a significant difference between the perception of parents/guardians about children's dental anxiety and the dental anxiety reported by them. Besides, there was no relationship between the parents'/guardians' perception of children's dental anxiety with their parents' dental anxiety, socioeconomic factors, last visit to the dentist, parents' reason for their last dental appointment, children's oral condition and type procedure performed.

\section{Collaborators}

A TRAVESSINI and JC BARASUOL, analysis and interpretation of data for the work; drafting and revising the work critically, final approval of the version to be published. JP SOARES, conception, design of the work, acquisition and analysis of the data, final approval of the version to be published. M CARDOSO, analysis and interpretation of data for the work; revising the work critically, final approval of the version to be published. M BOLAN, conception, design of the work, analysis and interpretation of data for the work; drafting and revising the work critically; final approval of the version to be published.

\section{REFERENCES}

1. Kanegane K, Penha SS, Borsati MA, Rocha RG. Ansiedade ao tratamento odontológico no atendimento de rotina. RGO, Rev Gaúch Odontol. 2006;52:111-14. 
2. Soares FC, Lima RA, Barros MVG, Dahllof G, Colares V. Development of dental anxiety in schoolchildren: A 2-year prospective study. Community Dent Oral Epidemiol. 2017;45(3):281-8. https://doi.org/10.1111/cdoe.12290

3. Abanto J, Vidigal EA, Carvalho TS, Sá SNC, Bönecker M. Factors for determining dental anxiety in preschool children with severe dental caries. Braz Oral Res. 2017;31:1-7. https:// doi.org/10.1590/1807-3107bor-2017.vol31.0013

4. Soares FC, Lima DSM, Barreto KA, Colares V. Factors associated with dental anxiety in children: a literature review. Psicologia, Saúde \& Doença. 2015;16:373-85.

5. Goettems ML, Ardenghi TM, Demarco FF, Romano AR, Torriani DD. Children's use of dental services: influence of maternal dental anxiety, attendance pattern, and perception of children's quality of life. Community Dent Oral Epidemiol. 2012;40(5):451-8. https://doi.org/10.1111/j.16000528.2012.00694.x

6. Oliveira MF, Moraes MVM, Evaristo PCS. Avaliação da ansiedade dos pais e crianças frente ao tratamento odontológico. Pesqui Bras Odontop Clin Integr. 2012;12:4839.

7. Barasuol JC, da Silva Assunção LR, Fraiz FC, Menezes JVNB. Oral health literacy as a predictor of dental anxiety in parents of children undergoing dental treatment. J Dent Child (Chic). 2017;84(3):125-31.

8. Colares V, Franca C, Ferreira A, Amorim Filho HA, Oliveira MCA. Dental anxiety and dental pain in 5- to 12-year-old children in Recife, Brazil. Eur Arch Paediatr Dent. 2013;14(1):15-9. https://doi.org/10.1007/s40368-012-0001-8

9. Soares FC, Lima RA, Santos CFBF, Barros MVG, Colares V. Predictors of dental anxiety in Brazilian 5-7years old children. Compr Psychiatry. 2016;6:46-53. https://doi.org/10.1016/j. comppsych.2016.01.006

10. Corah NL. Development of a dental anxiety scale. J Dent Res. 1969;48:596.

11. Hu LW, Gorenstein C, Fuentes D. Portuguese version of Corah's Dental Anxiety Scale: transcultural adaptation and reliability analysis. Depress Anxiety. 2007;24(7):467-71.

12. Corah NL, Gale EN, Illig SJ. Assessment of a dental anxiety scale. J Am Dent Assoc. 1978;97:816-9.
13. Ramos-Jorge ML, Pordeus IA. Por que e como medir a ansiedade infantil no ambiente odontológico. Apresentação do teste VPT modificado. Rev Ibero-am Odontop Odontol Bebê. 2004;7:282-90.

14. Organização Mundial da Saúde (OMS). Oral health surveys: basic methods. 5 ed. Geneva: ORH/EPID; 2013.

15. Vasiliki B, Konstantinos A, Nikolaos K, Vassilis K, Cor VL, Jaap V. Relationship between child and parental dental anxiety with child's psychological functioning and behavior during the administration of local anesthesia. J Clin Pediatr Dent. 2016;40(6):431-7.

16. Cianetti S, Lombardo M, Lupatelli E, Pagano S, Abraha I, Montedori A, et al. Dental fear/anxiety among children and adolescents. Asystematic review. Eur J Paed Dent. 2017;18(2):12130. https://doi.org/10.23804/ejpd.2017.18.02.07

17. Krikken JB, Wun AJV, Cate JMT, Veerkamp JSJ. Measuring dental fear using the CFSS-DS. Do children and parents agree? Int J Paed Dent. 2013;23(2):94-100. https://doi.org/10.1111/ j.1365-263X.2012.01228.x

18. Olak J, Saag M, Honkala S, Nõmmela R, Runnel R, Honkala $E$, et al. Children's dental fear in relation to dental health and parental dental fear. Stomatologija. 2013;15(1):26-31.

19. Nicolas E, Bessadet $M$, Collado V, Carrasco P, Rogerleroi $V$, Hennequin M. Factors affecting dental fear in French children aged 5-12 years. Int J Paed Dent. 2010;20(5):366-73. https:// doi.org/10.1111/j.1365-263X.2010.01054.x

20. Oliveira MMT, Colares V. The relationship between dental anxiety and dental pain in children aged 18 to 59 months: a study in Recife, Pernambuco State, Brazil. Cad Saude Publica. 2009;25(4):743-50. https://doi.org/10.1590/S0102$311 \times 2009000400005$

21. Ramos-Jorge J, Marques LS, Homem MA, Paiva SM, Ferreira MC, Oliveira Ferreira $F$, et al. Degree of dental anxiety in children with and without toothache: prospective assessment. Int J Paed Dent. 2012;23(2):125-30. https://doi.org/10.1111/ j.1365-263X.2012.01234.x

Received on: 23/11/2018

Final version resubmitted on: 22/8/2019

Approved on: 12/2/2020 